\title{
HASIL TANGKAPAN BELANGKAS DI PERAIRAN PANTAI TIMUR SUMATERA UTARA, PASCA PENETAPAN STATUS PERLINDUNGAN BERDASARKAN PERATURAN MENTERI LINGKUNGAN HIDUP DAN KEHUTANAN REPUBLIK INDONESIA NOMOR 20 TAHUN 2018
}

\section{THE CATCH OF HORSESHOE CRAB IN THE EAST COAST OF NORTH SUMATERA, AFTER ESTABLISHING PROTECTION STATUS BASED ON REGULATION OF THE MINISTER OF ENVIRONMENT AND FORESTRY REPUBLIC OF INDONESIA NUMBER 20 YEAR 2018}

\author{
KHAIRUL $^{1^{*}}$ ), ZUNAIDY ABDULLAH SIREGAR ${ }^{2}$ ) \\ 1,2) STKIP Labuhan Batu , Jl. Sisingamangaraja, No.126 A, km 3,5, Aek Tapa Rantauprapat. Indonesia \\ Email: khairulbiologi75@gmail.com
}

Diterima Mei 2019 dan Disetujui Juni 2019

\begin{abstract}
Abstrak. Belangkas merupakan hewan yang dilindungi oleh pemerintah indonesia. Populasinya di alam mengalami ancaman kepunahan, diduga karena pencemaran perairan, degradasi habitat dan penangkapan berlebih. Tujuan penelitian ini adalah untuk menetahui hasil tangkapan belangkas di perairan Pantai Timur Sumatera Utara, setelah ditetapkan sebagai satwa yang dilindungi oleh pemerintah. Penelitian ini merupakan penelitian eksploratif, dimana penentuan lokasi pengamatan melalui purposive random sampling. Belangkas ditangkap dengan menggunakan jaring insang dan dikutip dengan tangan. Penangkapan belangkas dilakukan selama 3 bulan pada masing-masing stasiun pengamatan, yang dimulai pada bulan April, Mei dan Juni tahun 2018. Hasil penelitian menunjukan jumlah belangkas yang tertangkap pada stasiun 1 ( 3 individu), stasiun 2 (4 individu), dan stasiun 3 (12 individu). Jumlah belangkas jantan yang tertangkap pada Stasiun 1 (2 individu) Stasiun 2 ( 2 individu), dan Stasiun 3 (8 individu). Jumlah belangkas betina yang tertangkap pada Stasiun 1 (1 individu), Stasiun 2 (2 individu), dan Stasiun 3 (4 individu)
\end{abstract}

Kata Kunci: Hasil Tangkapan Belangkas, Pantai Timur Sumatera Utara

\begin{abstract}
Horseshoe crab is an animal protected by the Indonesian government. Its population in nature is experiencing threats of extinction, allegedly due to water pollution, habitat degradation and over fishing. The purpose of this research is to know the catch-up on the east coast of North Sumatera, once designated as an animal protected by the government. This research is an exploratory study, where the determination of the observation site through purposive random sampling. The safe is captured by using the net Gill and hand sorting. The arrest of the safe was held for 3 months at each observation station, which began in April, May and June in 2018. The results of the study showed the number of safe deposit on the station 1 (3 indiviiduals), station 2 (4 individuals), and station 3 (12 individuals). The number of male safe is caught at Station 1 (2 individuals) station 2 (2 individuals), and station 3 (8 individuals). Number of female safe caught at Station 1 (1 individual), station 2 (2 individuals), and station 3 (4 individuals)
\end{abstract}

Keywords: Horseshoe Crab Catches, East Coast of North Sumatera

\section{PENDAHULUAN}

Belangkas termasuk hewan yang dilindungi, berdasarkan Surat Keputusan Menteri Kehutanan No. 12/ KPS -II/ 1987 dan Peraturan Pemerintah Nomor 7 tahun [1]. Badan Konservasi Sumber Daya Alam (BKSDA) telah menetapkan bahwa hewan ini termasuk yang dilindungi oleh undang-undang konservasi. Hewan ini di Indonesia lebih dikenal dengan nama Mimi mintuno [2].

Terakhir ditetapkan, berdasarkan [3] tentang penetapan jenis tumbuhan dan satwa yang dilindungi, yaitu pada lampiran nomor urut 792 untuk Belangkas Besar (Tachipleus gigas); 793 untuk Belangkas Tiga Duri (Tachipleus tridentatus); dan 794 untuk Belangkas Padi (Cardinoscorpius rotunndicauda). 
Hal : 21-25

Walaupun sudah masuk sebagai biota perairan yang dilindungi, namun kondisi populasi belangkas pada habitatnya diduga terus mengalami penurunan. Menurut [4] kajian mengenai belangkas di Indonesia sangat jarang dilakukan dan belum diketahui dengan jelas status populasinya. Penurunan populasi belangkas karena disebabkan telah terjadinya degradasi habitat, termasuk adanya penangkapan yang cukup intensif oleh nelayan [5].

Pantai Timur Sumatera Utara merupakan habitat belangkas, karena merupakan perairan yang mempunyai ekosistem pantai berpasir dan berlumpur serta ditumbuhi oleh hutan mangrove sebagai daerah pemijahan, pengasuhan dan mencari makan. Menurut [6] belangkas merupakan hewan yang hidup di dasar perairan berpasir dan berlumpur. Selanjutnya menurut [7] belangkas jenis C. rotundicauda mendiami daerah berlumpur, umumnya di perairan payau.

Sejak dikeluarkan beberapa kali Peraturan Pemerintah tentang penetapan belangkas sebagai hewan dilindungi sejak tahun 1987 sampai dengan tahun 2018, kajian terhadap belangkas terus digalakkan. Namun, tidak semua wilayah potensial penyebaran belangkas dapat dilakukan penelitian. Salah satunya adalah kawasan Pantai Timur Sumatera Utara. Sampai saat ini, belum ada laporan dari peneliti yang melakukan penelitian di kawasan ini. Data dan informasi ini sangat penting untuk mengetahui kondisi populasi belangkas di Perairan Pantai Timur Sumatera Utara.

\section{METODE PENELITIAN \\ Waktu dan Tempat}

Penelitian ini dilaksanakan selama 3 bulan yakni mulai April sampai dengan Juni 2019 di kawasan Pantai Timur Provinsi Sumatera Utara.

\section{Alat dan Bahan}

Tabel 1. Alat dan Bahan

\begin{tabular}{clll}
\hline No & \multicolumn{1}{c}{ Parameter } & \multicolumn{1}{c}{ Alat } & \multicolumn{1}{c}{ Bahan } \\
\hline 1 & Titik Koordinat & Glabal Positioning System (GPS) & - \\
2 & Sampling & $\begin{array}{l}\text { Jaring insang dan dikutip dengan tangan, serta } \\
\text { keranjang }\end{array}$ & Belangkas \\
3 & Transportasi & Sampan bermesin & - \\
4 & Dokumentasi & Kamera & Belangkas \\
5 & Identifikasi & Guide Book of Crustaceans (FAO) & Belangkas \\
\hline
\end{tabular}

\section{Jenis Penelitian}

Penelitian ini merupakan penelitian eksploratif. Penelitian Eksploratif merupakan studi dengan melakukan penelusuran, terutama dalam pemantapan konsep yang akan digunakan dalam ruang lingkup yang penelitian yang lebih luas dengan jangakauan konseptual yang lebih besar.

\section{Metode Penelitian}

Penelitian ini menggunakan metode purposive sampling. Purposive sampling adalah teknik menentukan titik pengambilan sampling dengan beberapa pertimbangan tertentu yang tujuannya agar data yang diperoleh nantinya bisa lebih representatif.

\section{Prosedur Penelitian \\ Penentuan Stasiun Pengamatan.} beda, yakni:

Stasiun pengamatan ditentukan berdasarkan karakteristik habitat belangkas yang berbeda-

1. Stasiun 1 (Ekosistem hutan mangrove Belawan Sicanang, Kota Medan)

2. Stasiun 2 (Pantai Sialang Buah, Kabupaten Serdang Bedagai)

3. Stasiun 3 (Pantai Kahona, Kabupaten Labuhan Batu)

\section{Teknik Penangkapan Belangkas}

Pengambilan sampel belangkas dilakukan dengan menggunakan jaring insang (gill net) yang ditebarkan sampai ke dasar perairan. Jaring insang di pasang pada stasiun pengamatan sebanyak 3 buah, hal ini dianggap sebagai ulangan. Pengambilan sampling dilakukan sebanyak 3 kali dan dilakukan 1 kali pada setiap bulannya.

Selain itu teknik pengumpulan sampel juga dilakukan dengan metode dikutip dengan tangan (hand sortir). Hal ini dilakukan untuk medan yang tidak memungkinkan dipasang gill net, namun 
Hal : 21-25

diduga merupakan daerah mencari makan. Belangkas yang ditangkap kemudian diukur panjang dan beratnya serta dihitung jumlahnya. Setelah selesai kemudian dilepaskan kembali untuk menjaga kelestariannya. Namun untuk jenis yang berbeda diambil lalu diawetkan dengan alkohol $70 \%$ untuk selanjutnya dilakukan identifikasi di Laboratorium Ekologi STKIP Labuhanbatu mengunakan buku identifikasi.

\section{Analisis Data}

Data hasil penelitian dibuat dalam bentuk tabulasi data dan dianalisis secara diskriptif kualitatif, kemudian dilakukan pembahasan berdasarkan literatur yang relevan.

\section{HASIL DAN PEMBAHASAN \\ HasilTangkapan Berdasarkan Bulan}

Pengambilan sampling belangkas dilakukan selama 3 bulan, mulai bulan April sampai dengan Juni 2019. Berdasarkan hasil tangkapan diperoleh pada Stasiun 1 sebanyak 3 individu, dengan rincian 1 individu pada bulan April dan 2 individu pada bulan Juni; Pada Stasiun 2 diperoleh 4 individu, 2 individu pada bulan April dan 2 individu pada bulan Mei; Pada Stasiun 3 diperoleh 12 individu, 2 individu pada bulan April, 4 individu pada bulan Mei, dan 6 individu pada bulan Juni. Selanjutnya data Hasil tangkapan Belangkas berdasarkan bulan dapat dilihat pada tabel berikut:

Tabel 2. Hasil Tangkapan Belangkas Selama Penelitian

\begin{tabular}{cccc}
\hline Stasiun Pengamatan & \multicolumn{3}{c}{ Jumlah Hasil Tangkapan (Bulan/ Individu) } \\
\cline { 2 - 4 } & April & Mei & Juni \\
\hline Stasiun 1 & 1 & - & 2 \\
Stasiun 2 & 2 & 2 & - \\
Stasiun 3 & 2 & 4 & 6 \\
\hline
\end{tabular}

Sumber: Data Hasil Penelitian (2019)

Jika dilihat dari tabel di atas, terjadi peningkatan jumlah hasil tangkapan pada setiap bulannya. Diketahui, pada bulan April ada 5 individu yang tertangkap, pada bulan Mei ada 6 individu, dan pada bulan Juni ada 8 individu. Hasil penelitian [8] memperkirakan kepadatan pada bulan Januari dan Februari adalah konsisten pada 0,97 $\pm 0,13$ dan 0,98 $\pm 0,19$ kepiting $\mathrm{m}^{-2}$, masing-masing. Kepadatan pada bulan Maret dan Juni, dari kuadrat yang lebih kecil daripada pada bulan Januari dan Februari, sedikit lebih rendah pada $0,60 \pm 0,09$ dan $0,57 \pm 0,08$ kepiting $\mathrm{m}^{-2}$ pada bulan masing-masing.

Namun, jika dibandingkan berdasarkan hasil tangkapan per stasiun pengamatan, maka pada stasiun 3 menunjukan jumlah hasil tangkapan tertinggi sebanyak 12 individu, diikuti Stasiun 2 (4 Individu), dan Stasiun 3 (3 Individu). Berdasarkan penelitian yang dilakukan [8] menunjukan bahwa masih ada populasi yang terus berkembang dari belangkas jenis Carcinoscorpius rotundicauda di Mandai (Kranji), dihitung berkisar dari 29.925 sampai 51.450 individu di area pencarian dataran berlumpur saja. Habitat berlanjut di sepanjang pantai dan menyeberang ke pantai yang berlawanan dari Selat, dimana belangkas kuda dapat ditemukan. Hal yang menunjukan kisaran kelimpahan ini cenderung meremehkan, karena akan ada tambahan individu di habitat yang bersebelahan dan mungkin juga di Selat di bawah tanda air pasang surut di perairan yang lebih dalam dari Selat Johor.

\section{Hasil Tangkapan Berdasarkan Jenis Kelamin}

Jenis kelamin belangkas yang tertangkap pada masing-masing stasiun pengamatan adalah sebagai berikut: Stasiun 1 diperoleh 2 jantan dan 1 betina, stasiun 2 diperoleh 2 jantan dan 2 betina, dan pada stasiun 3 diperoleh 8 jantan dan 4 betina.Selengkapnya data hasil tangkapan belangkas berdasarkan jenis kelamin dapat dilihat pada tabel berikut:

Tabel 3. Hasil Tangkapan Belangkas Berdasarkan Jenis Kelamin

\begin{tabular}{ccc}
\hline Stasiun Pengamatan & \multicolumn{2}{c}{ Jumlah Hasil tangkapan (Individu) } \\
\cline { 2 - 3 } & Jantan & Betina \\
\hline Stasiun 1 & 2 & 1 \\
Stasiun 2 & 2 & 2 \\
Stasiun 3 & 8 & 4 \\
\hline
\end{tabular}

Sumber: Data Hasil Penelitian (2019) 
Hal : 21-25

Hasil tangkapan berdasarkan jenis kelamin, maka dapat diketahui jumlah belangkas jantan lebih banyak tertangkap yakni 14 individu sedangkan jumlah betina yang tertangkap hanya berjumlah 7 individu. Perbandingan belangkas jantan dan betina berdasarkan hasil tertangkap adalah 2:1. Hasil penelitian ini jauh lebih sedikit bila dibandingkan dengan [6] yang mendapatkan jumlah jantan dan betinanya sebanyak 37 individu dan 29 individu.

Metode yang dilakukan di perairan selat Malaka juga bisa menjadi indikator eksploitasi berlebihan (over exploitation) dengan metode jaring di laut terbuka yang menahan peluang belangkas untuk mencapai area pantai untuk pemijahan. Strategi sejarah hidup Tachypleus sp. yang cenderung bermigrasi ke laut daripada tinggal di habitat pantai juga akan mempengaruhi jumlah panangkapan [9].

\section{Kesimpulan}

Penangkapan belangkas berdasarkan bulan menunjukan adanya perbedaan hasil tangkapan pada tiap-tiap bulannya. Penangkapan belangkas berdasarkan jenis kelamin menunjukan adanya perbandingan antara jantan dan betina, yakni 2:1. Hasil penelitian menunjukan bahwa populasi belangkas di kawasan Pantai Timur Sumatera Utara telah mengalami penurunan, hal ini diduga akibat dampak degradasi habitat, pencemaran air dan pengaruh penangkapan.

\section{Ucapan Terima Kasih}

Pada kesempatan ini penulis mengucapkan rasa terima kasih yang sebesar-besarnya kepada Direktorat Jenderal Penguatan Riset dan Pengembangan Kementerian Riset, Teknologi, dan Pendidikan Tinggi Republik Indonesia atas bantuan dana untuk Penelitian Dosen Pemula pada tahun 2018.

\section{DAFTAR PUSTAKA}

[1]. Mulya, M. B. 2004. Pelestarian, Pemanfaatan Sumberdaya Genetika Mimi Ranti (Carcinoscorpius rotundicauda) dan Mimi Bulan (Tachypleus gigas). Universitas Sumatera Utara.

[2]. Ciptono. 2006. Identifikasi Tahap-Tahap Embrional Pre-Moulting 'Horse-Shoe Crabs' (Limulus Polyphemus) Menurut Pola Perkembangan Normal. SEMINAR NASIONAL MIPA 2006 dengan tema" Penelitian, Pendidikan, dan Penerapan MIPA serta Peranannya dalam Peningkatan Keprofesionalan Pendidik dan Tenaga Kependidikan" yang diselenggarakanoleh FakultasMatematika dan IImu Pengetahuan Alam UNY, Yogyakarta.

[3]. Peraturan Menteri Lingkungan Hidup dan Kehutanan Republik Indonesia No. P.20/MENLHK/SETJEN/KUM.1/6/2018. (2018). Tentang penetapan jenis tumbuhan dan satwa yang dilindungi. Pada laman: http://ksdae.menlhk.go.id/assets/news/peraturan/P.20_Jenis_TSL_.pdf. Diakases tanggal 27 Juni 2019.

[4]. Meilana, L., Yusli Wardiatno, Nurlisa A Butet, dan Majariana Krisanti. (2016). Karakter Morfologi Dan Identifikasi Molekuler Dengan Marka Gen CO1 Pada Mimi (Tachypleus Gigas) Di Perairan Utara Pulau Jawa. Jurnal IImu dan Teknologi Kelautan Tropis. Vol. 8, No. 1: $145-158$.

[5]. R. Anggraini, Dietriech G. Bengen, dan Nyoman Metta N Natih. Struktur Populasi Dan Morfometri Belangkas Carcinoscorpius Rotundicauda, Latreille 1802 Di Pesisir Kampung Gisi Teluk Bintan Kepulauan Riau. Jurnal Ilmu dan Teknologi Kelautan Tropis, Vol. 9, No. 1: 211220.

[6]. Ahmad, S.A Samson, dan P. Taru. 2017. Karakteristik Habitat Belangkas (Horse Shoe Crab) Di Perairan Muara Badak Kecamatan Muara Badak Kabupaten Kutai Kartanegara Provinsi Kalimanta Timur. TFS, Vol 23 No. 1: 32-39. 
Hal : 21-25

[7]. Chatterji A, Abidi SAHJ .1993. The Indian horseshoe crab: a living fossil. J Indian Ocean Study $1: 43-48$

[8]. Cartwright-Taylor, L., Y.V. Bing, H.C. Chi, and L.S. Tee. 2011. Distribution and abundance of horseshoe crab Tachypleus gigas and Carcinoscorpius rotundicauda around the main island Singapore. Aquatic Biology. 13:127-136.

[9]. M. Razali, M. R., and Zaleha, K (2017) Fishery Aspect of Horseshoe Crab [Tachypleus gigas (Müller, 1785)] in the Peninsular Malaysia: Exploitation Status. Universal Journal of Applied Science 5(2): 11-15 